\title{
2 Consolidating Political and Governance Strength
}

Steve Tsang

In Steve Tsang \& Honghua Men (eds.), China in the Xi Jinping Era (Palgrave Macmillan, 2016), 17-40.

By the time Xi Jinping completed his two terms as General Secretary of the Communist Party of China (CPC) in the autumn of 2022 the Party will have celebrated its centenary (2021), and the People’s Republic of China (PRC) will have outlasted the Soviet Union by four years. These forthcoming landmarks are important points of reference for Xi. As China's leader Xi is committed to pre-empt a Soviet style implosion and to revive the Party and the country during his watch. The general direction to which Xi would like to take China is encapsulated in the China dream, which he articulated in public for the first time at 'the road to revival' exhibition at the National Museum in Beijing, shortly after he took power in November 2012. This determination was affirmed at the Third Plenum of the $18^{\text {th }}$ Party Congress held in November 2013. Although the Fourth Plenum (October 2014) focused on 'comprehensively advancing the rule of law', the overall objective of Xi was not changed. ${ }^{1}$

Essentially Xi is committed to restore China to greatness by building on 'socialism with Chinese characteristics'. ${ }^{2}$ He is keenly aware of the weaknesses within the political

\footnotetext{
${ }^{1}$ China (2014a) 'Communique of the $4^{\text {th }}$ Plenary Session of the $18^{\text {th }}$ Central Committee of CPC', http://www.china.org.cn/china/fourth plenary session/2014-12/02/content 34208801.htm, date accessed 7 August 2015.

${ }^{2}$ Xinhua Net (2012) Xi Jinping, 'Chengqian qihou jiwang kailai jixu chaozhe zhonghuanminzu weida fuxing mubiao fenyong qianjin', http://news.xinhuanet.com/politics/2012-11/29/c 113852724.htm, date accessed 30 May 2013.
} 
system, which makes it potentially vulnerable. While Xi acknowledges the risk that the PRC could follow the footsteps of other former Communist states and implode he does not share the worry Party leaders had in the early 1990s. Xi exudes immense confidence in China's political system and its prospect. ${ }^{3}$ To him the system is not fundamentally weak or faulted but it needs a good shake up and a strong leadership to function as an effective machinery for governance that delivers the national revival to which he is committed. The system that Xi has inherited is a consultative Leninist one, which took shape under the leadership of Jiang Zemin and Hu Jintao. The focus of reforms in the political arena is to reinforce and strengthen this system, not to replace it by an alternative system such as liberal democracy or by a restoration of Maoist totalitarianism or by a dictatorship.

The term ‘consultative Leninism’ was first used by Richard Baum in a paper published by the French Centre for International Studies and Research in 2007. ${ }^{4}$ I used the same term and developed it independently into an analytical framework for understanding the nature of the political system in the People's Republic of China (PRC) in an article in the Journal of Contemporary China in $2009 .^{5}$ The same analytical framework is used in this chapter to assess the direction and scope of changes in the political sphere in the coming decade.

The changes that $\mathrm{Xi}$ would like to introduce in the political sphere are tied closely to the goals encapsulated in the China Dream. In essence it is about restoring China's greatness

\footnotetext{
${ }^{3}$ Seeing Red (2013) Yu Gao, 'Beijing Observation: Xi Jinping the Man', http://seeingredinchina.com/2013/01/26/beijing-observation-xi-jinping-the-man-by-gao-yu/, date accessed 26 November 2013.

4 Stephen-t (2007) Richard Baum, 'The Limits of Authoritarian Resilience', http://www.stephent.com/pdf/the\%20limits\%20of\%20authoritarian\%20resilience\%20-\%20Baum.pdf, date accessed 31 May 2013.

5 Steve Tsang (2009) 'Consultative Leninism: China's new political framework', Journal of Contemporary China, vol.18, no. 62, pp. 865-880. There are parts of this paper which are based on the article cited above.
} 
as a rich country supported by a powerful modern military. The primary instrument to deliver the China Dream is the Communist Party, which Xi plans to reinvigorate through two mutually supportive initiatives. The first is to revitalise the Party as a Leninist instrument of control and governance. The anti-corruption drive is intended primarily to deliver this, in addition to restoring the reputation and credibility of the Party countrywide. The revival of the Maoist principle of 'the mass line' is adopted to enable the Party to direct public opinion and secure public support after it has ostensibly reached out to the general public for their views. The second initiative is to reassert the Party's narrative of history and reaffirm the legitimacy of the Party based on its 'great historical achievements' with the great tragedies that happened under Mao appropriately contextualized.

The consultative Leninist system Xi inherited from Hu has demonstrated its resilience. It has withstood two generational leadership successions, in 2002 and 2012, as well as a major potential crisis as the global financial crisis of 2007-9 threatened to engulf China. The public commitment by successive leaders including Xi to deepen reform reveals the system's inherent requirement that it must constantly adapt to sustain its resilience.

It is a system that reaffirms the basic Leninist nature of the political system as it greatly strengthens its capacity to respond to public demands, shapes public opinions, and builds up a strong sense of national pride. While this involves introducing considerable changes in the political arena, this system is meant to enable the CPC to reject Western or liberal democracy as a model for China. 'Chinese democracy' as interpreted and implemented under Xi does not tolerate any scope for the Party to lose power. When the Party refers to 'political reform' it does not imply changes that will lead to democratization as it is usually understood in Europe and North America. In the PRC it generally implies governance 
changes to strengthen the capacity of the Party to rule more effectively and efficiently or deepen 'socialist democracy’.

Following the analytical framework I put forth in 2009, this consultative Leninist system blends together the Leninist instrument of control with innovations from other sources. ${ }^{6}$ It has five defining characteristics:

- The Communist Party is first and foremost focused on staying in power, for which maintaining stability in the country and pre-emptively eliminating threats to its political supremacy are deemed essential.

- A focus on governance reform both within the Party and in the state apparatus in order to pre-empt public demands for democratization in the Western sense of the word.

- A commitment to enhance the Party's capacity to elicit, respond to and direct changing public opinion.

- A commitment to sustain rapid growth and economic development by whatever means and, where the party leadership deems politically expedient.

- The promotion of a brand of nationalism that integrates a sense of national pride in a tightly guided narrative that stresses the greatness of China's history and its civilization under the leadership of the Party.

\section{Preservation of Party Leadership}

Under the leadership of Xi Jinping, the Party reaffirms its right to rule in China on the basis that it will transform the China Dream from rhetoric into reality. The provision in the state constitution for the Party to play the leading role in the PRC remains the basic principle

${ }^{6}$ Ibid., p. 866. 
that underpins the political system. ${ }^{7} \mathrm{Xi}$ is determined that the party will continue as the 'vanguard party' and 'guardian of the people'. As such he will ensure the Party maintains, indeed, strengthens its long standing capacity to deal with dissent as well as devises and implements a development model that seeks to deliver growth, employment, stability, order, prosperity and improved governance for the ordinary people. Under Xi, the CPC will keep its Leninist structure, ethos and organizational principles and will remain totally dedicated to staying in power and exercising supervision over the state institutions and the media.

Notwithstanding expectations that the Third Plenum of the $18^{\text {th }}$ Central Committee (2013) would usher in a new phase of reform, there is a strong continuity with the pattern set in the last two decades. With the passing of Deng Xiaoping as the last strong man in the PRC in 1997, Jiang Zemin stressed that 'The whole Party must always maintain the spirit of advancing with the times and constantly extend Marxist theory into new realms ... give top priority to development in governing and invigorating the country and constantly break new ground and open up a new prospect in the modernization drive... [and] improve its Party building in a spirit of reform and constantly inject new vitality into itself. ${ }^{8}$ This marked the start of consultative Leninism. $\mathrm{Xi}$ is just as committed to making the Party adapt in order to stay in power. This is to be achieved, when the general conditions in the country are benign, by the Party supervising the government machinery in delivering improvements in governance, strengthening the authorities' narrative of developments in the country, reaching out to the general public, redressing public grievances and improving living conditions.

In the leadership change year of 2012, there were strong pent-up public discontent

\footnotetext{
${ }^{7}$ English People (1982) Constitution of the People's Republic of China, http://english.people.com.cn/constitution/constitution.html, date accessed 2 June 2014. ${ }^{8}$ English CPC (2006) 'Three Represents', http://english.cpc.people.com.cn/66739/4521344.html, date accessed 2 June 2014.
} 
over the scale and reach of corruption which caught public imagination as the powerful leader of Chongqing and Politburo member Bo Xilai was removed from office. ${ }^{9}$ Xi clearly saw this as a major challenge to the Party's governance capacity as corruption is highly corrosive of the Party’s Leninist discipline and therefore its ability to respond to challenges effectively. It is also damaging to the Party's credibility and legitimacy. Hence, Xi took up the anticorruption cause as soon as he took over power by promptly appointing Wang Qishan, widely seen as the member of the new Politburo Standing Committee most able to tackle corruption, to spearhead such a campaign. ${ }^{10}$ While it is questionable whether the anti-corruption drive will be able to eradicate systemic corruption, it already has a powerful salutary effect in dramatically curbing lavish official entertainment and ostentatious display of ill-gotten wealth by officials at all levels. ${ }^{11}$ The anti-corruption drive is essentially part of a party rectification operation designed to reinvigorate the consultative Leninist system, something Xi will keep going or even institutionalise; it should not be seen as a political campaign, which always gets wound down after a period of time.

The anti-corruption policy should reduce and contain the abuse of power but it will not change the nature of the political system. Indeed, the resultant enhancement to the governance capacity and credibility of the Party is meant to pre-empt popular demand for liberal democracy or constitutionalism. ${ }^{12}$ Under Xi, the Party will sustain a benevolent and efficient monopoly of power while it practises democratic centralism. As a consultative

\footnotetext{
9 SCMP (2012) AFP, 'Anti-corruption tsar hears calls for transparency', South China Morning Post, , http://www.scmp.com/news/china/article/1096511/anti-corruption-tsar-hears-calls-transparency, date accessed 31 May 2013.

${ }^{10}$ Economist (2013a) 'A corruption fighter: Calling Fire Chief Wang', The Economist, http://www.economist.com/news/china/21574022-wang-qishan-has-one-crucial-advantage-fightingcorruption-calling-fire-chief-wang, date accessed 31 May 2013.

11 Irish Times (2013) Clifford Coonan, 'Communist officials sidestep Xi's anti-corruption efforts', The Irish Times, http://www.irishtimes.com/news/world/asia-pacific/communist-officials-sidestep-xi-s-anticorruption-efforts-1.1380894, date accessed 30 May 2013.

12 Zheng Zhixue (2013) 'Renqing "xianzheng" de benzhi', http://theory.people.com.cn/n/2013/0529/c83855-21652535.html (accessed, 29 May 2013).
} 
Leninism system China under Xi will seek to use precision or well-focused repression and inducements to eliminate or neutralize challenges to the Party as soon as such challenges are detected. This should pre-empt or reduce the need to resort to dramatic large scale or summary repression. It does not mean that summary repression as a tactic will not be applied if the top leadership should see a challenge to the security and unity of the state. This applies not only in the western regions with a heavy concentration of minorities but also to the rest of the country. The perceived rise of a serious terrorist challenge of the Islamist nature in Xinjiang following a series of bombings in Urumqi in the spring of 2014 is likely to result in the wider use of summary, rather than precision, repression there. ${ }^{13}$ But precision repression remains the preferred option in the rest of the country.

\section{Enhancing Governance}

Consultative Leninism promotes 'good governance with Chinese characteristics'. What this means needs to be contextualized. 'Chineseness' in this formulation should not be confused with traditional Chinese culture or the original Confucian values. The traditional Chinese concept of 'the ideal government... is one which is efficient, fair, honest and paternalistic, yet non-intrusive vis-à-vis the life of the ordinary people'. ${ }^{14}$ The last requirement contradicts the basic nature of the Party as a Leninist institution, which is about proactively leading, directing and mobilizing the general population to support all aspects of development as the Party sees fit.

In defining good governance with Chinese characteristics the Party looks back into

13 China (2014b) Xinhua, 'President Xi vows severe punishment on terrorists', http://www.china.org.cn/china/2014-05/22/content 32460524.htm, date accessed 2 June 2014. ${ }_{14}$ Steve Tsang (ed.) (1995) A Documentary History of Hong Kong: Government and Politics (Hong Kong: Hong Kong University Press), p. 5. 
both its own relatively short history and China's long history for inspiration. It also examines ideas and experience from outside of China as it constructs an alternative to democratization that is suited to the 'special conditions of China'. In Xi's words 'with regard to our cultural tradition and those from outside the country, we must make the old serve the present and those originating in the West useful for China' today. ${ }^{15}$ Thus, while Xi advocates a revival of the Confucian tradition Leninism - a Russian import - is deemed no less Chinese for this purpose.

A particularly important set of lessons Xi insists on the Party learning are that from the implosion of Communism in the Soviet Union and Eastern Europe. ${ }^{16} \mathrm{Xi}$ felt that the most essential one was that nobody in the Communist Party of the Soviet Union (CPSU) 'was man enough to stand up and resist’ the like of Mikhail Gorbachev. ${ }^{17}$ Since he took office Xi has stressed the importance of returning to traditional Leninist discipline to pre-empt the risk of the Party following the fate of the CPSU. ${ }^{18}$ The Party has further examined the experience of the 'Asian tiger economies' under authoritarian rule, particularly that of Singapore. ${ }^{19}$ The final product is, however, what the Party chooses to put together regardless of their origins, which it labels as a distinctly modern Chinese approach. The Party's definition of what is Chinese is meant to be final.

\footnotetext{
${ }^{15}$ CPC People (2013) Renmin Ribao and Xí Jinping, 'Xionghuai daju bawo dashi zhuoyan dashi nuli ba xuanchuan sixiang gongzuo zuode genghao', http://cpc.people.com.cn/n/2013/0821/c6409422636876.html, date accessed 27 Aug. 2015.

${ }^{16}$ Joseph Fewsmith (2001) China Since Tiananmen: The Politics of Transition (Cambridge: Cambridge University Press), 52-3.

17 China Digital Times (2013) 'Leaked Speech Shows Xi Jinping's Opposition to Reform', http://chinadigitaltimes.net/2013/01/leaked-speech-shows-xi-jinpings-opposition-to-reform/, date accessed 3 June 2013.

${ }^{18}$ NY Times (2013) Chris Buckley, 'Vows of Change in China Belie Private Warning', New York Times, http://www.nytimes.com/2013/02/15/world/asia/vowing-reform-chinas-leader-xi-jinping-airs-othermessage-in-private.html?pagewanted=all\& $r=0$, date accessed 31 May 2013.

${ }^{19}$ Chen Feng (1993) 'Xinjiapo Remin Xindongdang minzhu shehuizhuyi mowu jichi jiejian yiyi', Guoji Gongyun Shi Yanjiu, no.1, p. 5-10.
} 
The instrument to deliver good governance is the Party itself. As such it requires constant reform and updating. The Party seeks to do so by 'promoting a new generation of leaders, reformulating its ideological content, appealing to nationalist impulses in society, strengthening its organizational apparatus throughout the country, and opening the channels of discourse within the party and between the party-state and society. ${ }^{20}$ Such an approach, which is reinforced by increasing institutionalization and merit based promotion, has continued under Xi.

More specifically the Party has introduced reforms in the political arena aimed at enhancing its own capacity and that of the state to govern effectively. The Party uses 'a mix of measures to shore up popular support, resolve local protests, and incorporate the beneficiaries of economic reform into the political system'. ${ }^{21}$ After Hu Jintao succeeded Jiang Zemin the Party quietly started to re-emphasize selectively some Maoist ideas or practices, for example, the principle of democratic centralism. ${ }^{22}$ Hu saw a greater need for the Party to deliver social justice in order to pre-empt discontent in the countryside from developing into a major source of instability ${ }^{23}$. Hu publicly advocated that the Party should 'devote themselves in building a government "by the people, for the people", and one that ensures all Chinese enjoy the fruits of the country's economic development'. ${ }^{24}$ He took the view that 'the biggest danger to the Party ... has been losing touch with the masses' and the Party leadership must therefore 'focus on the core issue of the inextricable link between the Party and the

\footnotetext{
${ }^{20}$ David Shambaugh (2008) China's Communist Party: Atrophy and Adaptation (Washignton DC: Woodrew Wilson Center Press), p. 9.

${ }^{21}$ Bruce Dickson (2005) 'Populist Authoritarianism: China's Domestic Political Scebe', China's Communist Party, p. 37.

22 Wang Yang (2006) Xin shiqi Dang de ganbu zhidu jianshe (Beijing: Zhonggong dangshi chubanshe), p. 354.

${ }^{23}$ David Shambaugh (2008) China's Communist Party, p. 114-5.

${ }^{24}$ English People (2008) 'Chinese president urges improved public service in gov't', http://english.people.com.cn/90001/90776/6359481.html, date accessed 2 June 2014.
} 
masses’ ${ }^{25} \mathrm{Xi}$ has embraced this approach with a vengeance. Xi is not promoting a full scale Maoist restoration. Xi can see how effective some of the Maoist mobilization and propaganda methods were and intends to make the most of them. Xi and his cohort who, in an important sense, inherited power from their parents are not apologetic about their inheritance and are comfortable using Maoist methods as they see fit.

\section{Increasing institutionalization}

Consultative Leninism relies on institutionalization to make Chinese politics less volatile. The most important achievement in this regard is the introduction of an institutionalized way to manage succession. When Jiang Zemin's 'third generation' leadership handed over to Hu Jintao’s ‘fourth generation' leaders in 2002-3 it was the first time that an heir-apparent successfully took over as planned. This is a significant landmark as all previously anointed successors, from Liu Shaoqi to Zhao Ziyang ended their careers in dramatic and in most cases tragic circumstances. Hu's relatively uneventfully succession to Jiang set a precedent.

This practice was followed and indeed strengthened at the $18^{\text {th }}$ Party Congress a decade later. On this occasion, Hu passed on both the offices of General Secretary of the Party and the Chair of the Central Military Commission to Xi and formally retired. In contrast, his predecessor Jiang hung on to the latter position for two years after relinquishing the Party leadership in 2002. 2012-13 was also the first time in the history of the PRC when the new party chairman and premier emerged from an agreement reached in the previous Party Congress five years earlier, and was not the result of having been anointed by a

\footnotetext{
${ }^{25}$ Andrew J. Nathan and Bruce Gilley (eds.) (2002) China's New Rulers: The Secret Files (London: Granta Books), p. 193-4.
} 
strongman. Even by the standards of the post-Mao era this is a major landmark, as Deng had in fact anointed three direct and one indirect successor. Among those directly anointed, namely Hu Yaobang, Zhao Ziyang and Jiang Zemin, only the last completed his term of office without having been removed by fiat. The indirect successor was Hu Jintao himself.

Despite all the drama and rumours that appeared in the media ahead of the $18^{\text {th }}$ Party Congress (2012) and the intensity of tough bargaining behind the scene, the politics of succession has become sufficiently institutionalized that it is now nearly predictable, at least for the headship of the Party and of the State Council. The old practice of the paramount leader anointing a successor has now been replaced by a new one, which is still at the early stage of being institutionalized. It involves the existing top leadership collectively choosing their key successors and placing them in apprenticeship for five years before ascending to the top offices, as General Secretary of the Party and Premier of the state. The handing over of power is not democratic in the Western sense but it is structured, stable and basically predictable - indeed, much more predictable than possible in a democratic system. As a political system consultative Leninism supports collective leadership with an identifiable top leader but limits (though it cannot eliminate) the scope for the rise of a strongman.

At the third plenum of 2013, Xi strengthened the institutionalization of policy making on the most important challenges the PRC will face by creating two new top level agencies. The first is the State Security Council (SSC). The other is the Leading Small Group for Deepening Reform (LSGDR). By taking charge of them personally Xi ensures that he, as the leader of both the Party and the country, coordinates and directs the most important policy issues. While Xi has already proved that he is a more assertive and powerful leader than $\mathrm{Hu}$ after only one year in office, he is apparently seeking to exercise such authority through the 
two new institutions rather than asserting himself by fiat as a strongman normally would.

Although details on how the two new agencies work in practice are not yet available, it is almost certain that the SSC will be responsible for both internal and external security. Whether internal or external security takes precedent is a moot point, as both are essential for the legitimacy and continuation of the Party in power. Internal security will in reality take precedent mainly because the PRC does not face any external threat in the foreseeable future whereas the risk of an internal threat cannot be eliminated fully. Xi's awareness of the vital significance of internal security was fully revealed in his stress of the need to pre-empt the rise of a Gorbarchev figure and of his commitment to tighten control over the media and dissidents. In December 2013, the Party issued new guidelines to strengthen management of the media. This was intended to 'bolstering core socialist values and pooling positive energy to realize the Chinese dream of national rejuvenation'. ${ }^{26}$ This focus on domestic security was reinforced by the introduction, in parallel, of an Air Defence Identification Zone (ADIZ) a month earlier. Given the implications for China's relations with its neighbours and the rest of the world, it was impossible for the ADIZ to have been introduced without Xi's approval, though there is no evidence to suggest this was the first act of the SSC. The pushback from China's neighbours to the ADIZ underlines the importance for setting up a top level coordinating body for state security. The SSC is undoubtedly intended to fulfil such a purpose in co-ordinating all relevant government and party organs to ensure matters of state security are implemented in accordance with the decisions of the top leadership.

Xi’s taking charge of the LSGDR was formally announced at the end of 2013, and this confirmed Xi's commitment to use the Party as the key instrument to take reform forward.

${ }^{26}$ Xinhua Net (2013a) 'China Focus: China promotes core socialist values', http://news.xinhuanet.com/english/china/2013-12/24/c 132990379.htm, date accessed 30 December 2013. 
The most notable change thus introduced is to assign this portfolio not to the Premier, who is primarily responsible for managing the economy, but to the Party General Secretary, whose primary focus is politics and setting the general direction for development. This represents either a diminishing of the Premiership or a new emphasis on reform not being primarily a technical matter of managing the economy. It is easy to see this as reflecting the former, implying a factional seizure of power since Xi and Premier Li Keqiang do not share the same factional power base. ${ }^{27}$ However, there is no sign of serious tension between $\mathrm{Xi}$ and Li over this new arrangement. It is more likely that the change reflects a re-emphasize on the Leninist tradition of the Party, in line with the trend since the $18^{\text {th }}$ Party Congress. As far as can be ascertained General Secretary $\mathrm{Xi}$ is taking personal charge to ensure the Party will greatly strengthen its own capacity to deepen reform by first imposing tight discipline on party members, with Li keeping his position as the number two ranking leader in the Party. It implies that the top leadership under Xi intends a reinvigorated party to take the lead and direct the next stage of reform - in tune with consultative Leninist system. ${ }^{28}$

\section{Strengthening consultative capacity}

The Party's formal commitment to and its assertion that it already practises ‘democracy’ needs to be put in context. 'Socialist democracy’ in China requires electoral outcomes to be predictable and to deliver results approved by the Party beforehand. The chief mechanism the Party relies on to secure this is the principle of democratic centralism, which governs 'intra-party democracy'. Under Xi this mechanism is to be reinforced by 'the mass

\footnotetext{
${ }^{27}$ SCMP (2013) Gary Huang, 'Xi Jinping to head reform panel, taking another role from premier', South China Morning Post, http://www.scmp.com/news/china/article/1393479/xi-jinping-head-reformpanel-taking-another-role-premier, date accessed 31 December 2013.

${ }^{28}$ Xinhua Net (2013b) 'Zhonggong zhongyang zhengzhiju jueding chengli zhongyang quanmian shenhua gaige lingdao xiaozu' , http://news.xinhuanet.com/politics/2013-12/30/c 118771223.htm, date accessed 30 December 2013.
} 
line', based on the Maoist principle of 'from the masses and to the masses'. In essence this means the Party must go to the masses or 'patriotic citizens' to collect and collate ideas from them, then organize and otherwise add new input to produce a coherent and constructive set of policies and then take them back to the masses, educate and otherwise induce the masses to embrace such ideas as their own. ${ }^{29}$ As far as the Party is concerned its leadership 'is a fundamental guarantee for the Chinese people to be masters in managing the affairs of their own country'. ${ }^{30}$

Consultative Leninism is meant to pre-empt democratization as the term is understood by political scientists in the West. What it is designed to deliver is 'consultative democracy'. This is deemed 'a special advantage that China enjoys under socialist democracy', and a 'manifestation of the mass line'. ${ }^{31}$ As it is explained in a Third Plenum document, 'policy decisions are not made and implemented without first conducting widespread consultation under the leadership of the Party, which will focus on the important problems of socioeconomic development, and bear in mind the practical issues of the interests of the masses. ${ }^{32}$ Under Xi, the Party is committed to resurrect fully the mass-line.

It should not be assumed that deepening the Party's version of 'consultative democracy' that includes the re-introduction of some Maoist practices is incompatible with features commonly seen in democratization. Indeed, the Party is interested not only in

${ }^{29}$ Tony Saich (2004) Governance and Politics of China, $2^{\text {nd }}$ edn (Basingstoke: Palgrave Macmillan), $p$. 44. The concept of 'the masses' is essentially a Maoist concept. The nearest meaning to such a term is 'patriotic' citizens, with the Communist Party holding the right to define what 'patriotic' means. The issue of patriotism is examined further towards the end of this paper.

${ }^{30}$ Kerry Brown (2011) Ballot Box China: Grassroots Democracy in the Final Major One-party State (London \& New York: Zed Books), p. 40.

${ }^{31}$ Xinhua Net (2013c) 'Shouquan fabu: Zhonggong zhongyang guanyu zhongyang quanmian shenhua gaige ruoganzhongda wenti de jueding', http://news.xinhuanet.com/politics/201311/15/c 118164235.htm, date accessed 30 December 2013.

32 Ibid. 
expanding good governance practices but also in allowing for a greater scope for civil liberties and for political participation for the overwhelming majority of the citizenry.

Dissidents who are deemed by the Party as subversive of the national interest are excluded. Indeed, they have their scope to do so more tightly restricted than previously, as the Party itself becomes more effective as an instrument to govern under Xi. But the number of dissidents in China who fall into such a category is a small fraction of the total population.

In terms of greater political participation the most important general elections in China are not those for the National People’s Congress but for the Communist Party’s national congress. At the $17^{\text {th }}$ Party Congress, held in October 2007, the party leadership allowed $15 \%$ of nominees to fail to get elected. ${ }^{33}$ At the $18^{\text {th }}$ Party Congress of November 2012, 9.3\% of those nominated for Central Committee membership were required to accept 'electoral' defeat, whereas the percentage was set at the higher figure of $11.3 \%$ for those nominated as alternate members of the Central Committee. ${ }^{34}$ The Chinese government also experimented with township level elections since the turn of the century on the basis of experimentation with village level elections introduced since the 1980s. ${ }^{35}$ Such developments do not amount to genuine democratic exercises as defined in the West, since the Party can and generally does secure its desired electoral outcomes, but they do enlarge the scope for election. ${ }^{36}$

\footnotetext{
${ }^{33}$ John L. Thornton (2008) 'Long Time Coming: Prospect for Democracy in China', Foreign Affairs, vol.87, no.1, p. 8-9.

${ }^{34}$ China (2012a) Xinhua, 'New China Party leadership elected', http://www.china.org.cn/china/18th cpc congress/2012-11/14/content 27108963.htm, date accessed 31 May 2013.

35 Tianjian Shi (2000) 'Economic Development and Village Elections in Rural China' in Suisheng Zhao (ed.), China and Democracy: Reconsidering the Prospects for a Democratic China (New York: Routledge), p. 244-6.

${ }^{36}$ Deliberative and incremental steps in increasing the element of election are part of democratization. In the case of Taiwan, for example, local elections from the 1950s onwards helped the democratization process once the Kuomintang authoritarian regime under Chiang Ching-kuo accepted the need to democratize in the late 1980s, even though such elections in the 1950 s were not particularly democratic or meaningful at the time.
} 
The Party has also made a point in consulting individuals and organizations outside itself than before. Important gestures underlining the Party and the government's commitment to do so range from reaffirming the right of existing consultative institutions to criticize specific government policies to the use of the new media as an opinion forum, to allowing greater scope for civil society to operate. ${ }^{37}$ Indeed, the Party revived the Chinese People's Consultative Political Conference (CPPCC), which includes other political parties, as an institution of consultation. As such the CPPCC is now asked by top level leaders like Yu Zhengsheng 'to better exert its role as a political consultative body' ${ }^{38}$ Non-Communist individuals of considerable personal achievements have also been co-opted to join the central government. Dr Wan Gang, President of Tongji University, has consequently served as Minister of Science and Technology since 2007. Likewise, Dr Chen Zhu, a haematologist and Vice President of the Chinese Academy of Sciences, was appointed Minister of Health from 2007 to 2013. Although such appointments represent primarily the application of a classic United Front idea to 'attract outstanding individuals from all over for the cause of the Party and country', it was a significant step in strengthening the non-exclusive element of consultative Leninism. ${ }^{39}$

As to the new media, which can be important instruments for undermining authoritarian regimes, the Chinese authorities not only monitor and control them vigorously but also adopt them for consultation or reaching out to the masses. Starting in 2007 the State Council has used its official website to collect opinions on draft laws and regulations. Even

\footnotetext{
${ }^{37}$ For enlarging the scope for civil society, see discussions below regarding the rescue and relief efforts during the Sichuan earthquake of 2008.

38 People Daily (2013) Xinhua, 'CPPCC urged to play bigger role', http://english.peopledaily.com.cn/90785/8187228.html, date accessed 2 June 2014.

${ }^{39}$ China (2012b) 'Report of Hu Jintao to the 18th CPC National Congress', http://www.china.org.cn/china/18th cpc congress/2012-11/16/content $2713754012 . \mathrm{htm}$, date accessed 2 June 2014.
} 
top leaders prefer to project an image that they can be accessible via the new media. When he was Premier, Wen Jiabao maintained a presence on Facebook. ${ }^{40}$ As General Secretary of the Party Hu Jintao held online discussions in the Renmin Ribao’s ‘strong country forum' in 2008. ${ }^{41} \mathrm{Xi}$ Jinping approached this differently. In an importance sense he went further by allowing photographs of him buying and eating a meal of steamed buns and sharing a table with citizens of Beijing in a local restaurant being circulated on Weibo, before it was showcased on Xinhuanet in late 2013. ${ }^{42}$

With regard to non-government organization (NGO) the Party under Xi is keen to ensure the Party plays a leadership role in directing the efforts of NGOs. The approach adopted is to treat NGOs collectively like a bird in a cage. The Party is prepared to enlarge the cage as it sees fit but a cage is nonetheless maintained. This is to give NGOs sufficient scope to operate in the non-critical realm while its ambition to extend its scope to the critical realm is contained so that genuine civil society cannot emerge and pose a threat to the Party. ${ }^{43}$

\section{Economic pragmatism}

In reiterating the Party’s commitment to deepen reform and rebalance the economy, $\mathrm{Xi}$ has acted in line with the requirement of consultative Leninism and adhered to economic pragmatism. The 'bird cage approach’ for managing the economy, as expounded by party

\footnotetext{
40 Wen's Facebook (2009) http://en-gb.facebook.com/pages/-Wen-Jia-bao/13823116911, date accessed 12 February 2009.

${ }^{41}$ Danwei (2008) 'Online chat with Hu J intao', Danwei, http://www. danwei.org/internet/president hu_jintao talks to n.php, date assessed 2 June 2014.

${ }^{42}$ Xinhua Net (2013d) 'Xi Jingping paidui mai baozi,jizi maidan duanpanzi', http://news.ifeng.com/mainland/detail 2013 12/28/32553245 0.shtml, date accessed 31 December 2013.

${ }^{43}$ Although the term 'civil society' is among seven concepts that are now required not to be used in universities, NGOs are not in fact banned under Xi. Global Voices (2014) Oiwan Lam, 'Chinese Government Bans Seven 'Speak-Not' Subjects', http://globalvoicesonline.org/2013/05/16/chinesegovernment-bans-seven-speak-not-school-subjects/, date accessed 2 January 2014.
} 
elder Chen Yun in the Dengist period, is still practised, though the cage has already been enlarged so much that it is not normally noticeable to most ordinary Chinese citizens. The basic principle remains that the Party will enlarge the cage as long as the performance of the bird (or the economy) justifies it and it is safe to do so. But the Party will reduce the cage should it become necessary to sustain the consultative Leninist system in place. A key limitation of this approach is that it is essentially a blunt instrument, as reducing the size of the cage invariably causes unintended consequences. This being the case, the enlargement of the cage has only been allowed in a carefully calibrated incremental basis. The scale of changes so far is the result of over 30 years of carefully managed expansion.

Notwithstanding the dramatic transformation over three decades of reform China's economy is still, by design, not a free market one though it is also no longer a command economy. It is a mixed one where private capital now has huge scope to invest in almost whatever it deems the most profitable lines of manufacturing, trade or service provision. It is also one where state or publicly owned enterprises enjoy great privileges and government patronage, and are still subject to government direction. In a nutshell the Party has enlarged the bird cage so much that the bird has largely developed without finding itself seriously constrained by the cage most of the time. But the cage has not been and will not be removed.

As Xi leads the way to re-work the strategy to rebalance the economy in the coming decade, he is exploring ways to manage the bird cage in a smarter way. There is no doubt that under Xi the Party will continue to consult the country's best economists and others with the requisite expertise, but the Leninist nature of the Party will also assert itself. The creation of the LSGDR should strengthen the capacity of the Party to control and enable it take bolder steps forward in rebalancing the economy. This was reflected in the Third Plenum's 
commitment to allow the market to play not just a 'basic' but 'a decisive role in resource allocation' in order to 'give better play to the role of government'. ${ }^{44}$

To rebalance the economy essentially means that it needs to make the economy much more efficient as well as less dependent on growth driven by export and infrastructural investments, and more dependent on domestic consumption and the market. This is not a new recognition. When he was Premier, Wen Jiabao publicly acknowledged this. What are needed are:

(i) widening the social safety net and raising household incomes and, ultimately, consumption;

(ii) removing the distortions in relative prices - mainly in the exchange rate and input costs - to exploit real comparative advantages and make the model more robust;

(iii)reducing the government's interference in the allocation of resources; and

(iv)liberalizing the financial system, which would allow for a more efficient and effective intermediation of savings. ${ }^{45}$

What is getting more pressing is for the Chinese Government to deal with the debt problems that mushroomed as a corollary of the economic stimulus packages since the global financial crisis threatened China. A majority of the loans taken out for this purpose that has matured has only been rolled over, not repaid. ${ }^{46}$ They will need to be settled in the next few years. What it will take to rebalance the economy is not unknown to the Party. The difficulty is in implementing them without putting the stability of the system at risk.

\footnotetext{
${ }^{44}$ English People (2013) Xinhua, 'China's emphasis on market's 'decisive' role to boost economic efficiency', http://english.people.com.cn/business/8456596.html, date accessed 1 January 2014. 45 Ettore Dorrucci, Gabor Pula and Daniel Santabárbara (2013) China's Economic Growth and Rebalancing (ECB Occasional Paper 142), p. 45.

${ }^{46}$ Financial Times (2013) Simon Rabinovitch, 'China confident it aced local debt audit exam', The Financial Times, http://www.ft.com/cms/s/0/88b02c30-71c3-11e3-adbd00144feabdc0.html\#axzz2p9GgH0wJ, date accessed 1 January 2014.
} 
Whether under Xi’s leadership, the consultative Leninist system will be able to do what $\mathrm{Hu}$ and Wen failed to deliver in this regard in the previous decade remains to be seen. $\mathrm{Xi}$ has chosen to strengthen the Party and his grip over it as the prerequisite in this endeavour. What is being put in place is a capacity to manage the enlargement of the birdcage in a smarter way. The intention is to enlarge the birdcage substantially but not in every direction, so that the market can indeed play a 'decisive role' but without posing a threat to the integrity of the consultative Leninist system.

\section{Nationalism as the new ideology}

The last defining feature of consultative Leninism is the promotion of nationalism as the ideological force that binds the country together under the leadership of the Party. Xi is a nationalist. His advocacy of the China dream takes the Party sponsorship of nationalism to a level higher than hitherto. But in so doing he is merely reinforcing an existing trend. This process started as Communism in effect ceased to function as the state ideology after 1989. It was in part a reaction to the events in Eastern Europe and the Soviet Union as the Chinese establishment feared social and national disintegration following 'the decline of the traditional ideology'. ${ }^{47}$ It was also because the Party intended to pre-empt Western values and beliefs from captivating Chinese citizens living in an ideological void. ${ }^{48}$ With consultative Leninism replacing the strongman politics of Deng Xiaoping, the promotion of this new ideological binding force was essential to keep the system function effectively. Xi Jinping seeks to use 'traditional faiths in the hope these will help fill a [moral] vacuum created by the country's breakneck growth and rush to get rich'. ${ }^{49}$

\footnotetext{
47 Zheng Yongnian (1999) Discovering Chinese Nationalism in China: Modernization, Identity, and International Relations (Cambridge: Cambridge University Press), p. 51.

${ }^{48}$ Chen Shaoming (1996) 'Minzu zhuyi: Fuxing zhi dao', Dong Fang, no.2, p. 74.

49 UK Reuters (2013) Benjamin King Lim and Ben Blanchard, 'Xi Jinping hopes traditional faiths can
} 
The choice of nationalism as the new though informal state ideology is meant to enhance the Party's capacity to stay in power on two mutually reinforcing ways. It is to provide a new basis for legitimacy and to serve as a new rallying force to develop a national aspiration around the leadership of the Party. After 1989 the Party 'moved quickly to position themselves as the defenders of China's national pride' and unity. ${ }^{50}$ The historical narrative chosen for this purpose is a pan-Chinese one. It is, however, based on a Han-centric view of the history of greater China. The nationalism thus promoted encourages Chinese nationals to identify with a rising China under the leadership of the Party in juxtaposition against the West that is portrayed as uncomfortable with China's resurgence and historic unity. ${ }^{51}$

This has not been diminished under Xi despite his commitment to defend the Maoist heritage of the Party and the PRC, which should not be confused with an attempt to revive Communism as the state ideology. On the contrary Xi uses nationalism, not Maoism, as the ideological base for the Party's legitimacy. Within a month of his elevation, Xi explained to sailors in Guangzhou that the China dream was about national revival, and it was about both the building of a strong country and powerful armed forces that should be totally loyal to the Party. ${ }^{52}$ His invocation of national victimhood in China’s ‘century of humiliation' has led to foreign observers seeing him as unashamedly appealing to emotion. ${ }^{53}$ As elaborated in the

\footnotetext{
fill moral void in China', Reuters, http://uk.reuters.com/article/2013/09/29/us-china-politics-vacuumidUSBRE98S0GS20130929, date accessed 2 June 2014.

50 Zhao Suisheng (2005-6) 'China's Pragmatic Nationalism: Is It Manageable?' The Washington Quarterly, vol.29, no.1, p.134.

${ }^{51}$ The large public outburst of nationalism when the Olympic torch relay outside of China met with large scale public protests in April 2008. For a strong representation of some Chinese nationalists' frustrations, see China Digital Times (2008) 'My Friends, What Do You Want From Us?', China Digital Times, http://chinadigitaltimes.net/2008/04/my-friends-what-do-you-want-from-us/, date accessed 2 June 2014.

52 BBS (2012) Xinhua, 'Xi Jinping kaocha Nanhai jiandui, guanmo junyan yu guanbing gongjin wucan', http://bbs.tiexue.net/post 6465710 1.html, date accessed 31 May 2013.

${ }^{53}$ Economist (2013b) 'Xi Jinping and the Chinese dream', The Economist, http://www.economist.com/news/leaders/21577070-vision-chinas-new-president-should-serve-hispeople-not-nationalist-state-xi-jinping, date accessed 31 May 2013.
} 
Party's theoretical journal, Qiushi, the China dream is about 'merging the dreams of individual with the dream of the country, of the nation, and of the people, and to put the interest of the individual, of the country, of the nation and of the people together as a whole' ${ }^{54}$ This focus on national revival in Xi's China dream suggests that he is even more committed than his predecessor to use nationalism as the state ideology to galvanize the country in support of consultative Leninism.

Under Xi the Party continues to use an extensive propaganda and educational campaign to indoctrinate the people in patriotism. It is one that requires the citizens of the PRC to participate in affirming 'the rightness and acceptability of the state, its values, policies and agencies'. ${ }^{55}$ The core of this campaign is to emphasize 'how China's unique national conditions make it unsuitable to adopt Western style liberal democracy' and how China's existing political system helps to 'maintain political stability, a prerequisite for rapid economic development’ ${ }^{56}$ By ‘[r]einforcing China’s national confidence and turning past humiliation and current weakness into a driving force for China's modernization' the Party has transformed nationalism into 'an effective instrument for enhancing [its] legitimacy'. ${ }^{57}$ The intention is to instil in the mind of the Chinese people a sense of pride in China and its development that is inseparable from the leadership of the Party or a strong feeling of 'my government right or wrong'. The pursuit of the China dream and the sustaining of the consultative Leninist system require this.

\section{Conclusions}

54 QS Theory (2013) Zhongguo shenhuikexue yuan Zhongguo tese shehuizhuyi lilun tixiyanjiu zhongxin, 'Ningju Zhongguo liliang shixian weida mengxiang', http://www.qstheory.cn/zxdk/2013/201311/201305/t20130527 234345.htm, date accessed 3 June 2013.

55 David Kelly (2006) 'Citizen Movements and China's Public Intellectuals in the Hu-Wen Era', Pacific Affairs, vol.79, no.2, p. 201.

56 Zhao, 'China's Pragmatic Nationalism', p. 135.

57 Ibid. 
Xi Jinping clearly intends to leave his marks. Since he assumed power, he has embraced consultative Leninism as the basis to build the China dream. All the indications so far are that he will develop the potential of the consultative Leninist system to the full. Xi has shown that he appreciates the advantages of this system. It gives China arguably as resilient a political system as it can have without democracy. The resilience is rooted in the capacity to control inherent in what remains an essentially Leninist political machinery. It is strengthened by incorporating various consultative elements and a new ideology that has much more ready appeal than Communism. By modernizing the regime’s capabilities to monitor and direct public opinion and instil a sense of patriotic duty on its citizens to support the government, the Party has built up a significant capacity to deflect public discontent away from itself. By enhancing its ability to detect challenges as they emerge and remove most of them, either by co-optation or by relatively well-focused repression, before they become major threats to the system, consultative Leninism lowers the need to resort to large scale summary repression. This, in turn, reduces exposure to risks that can destabilize the system in a fundamental way.

$\mathrm{Xi}$ is committed to make the consultative Leninist system work better. He understands that it is not a static system but one that needs to adapt to the changing environment so that the Party will stay in power and direct China's development. The big differences between his approach and that of Hu Jintao lies in his willingness to drive the Party much harder to make the China dream a reality within a decade, and to take risk. Xi appears ambitious and driven. He articulates confidence in the system's ability to form the foundation for China to secure its re-emergence as a great power of the first league. He seeks to do so by reinvigorating the Party so that it can perform as a Leninist instrument for control and for directing the next 
stage of reform as well as for reaching out to the masses more effectively. The launch of the anti-corruption drive after the $18^{\text {th }}$ Congress was but the first step in this process. $\mathrm{Xi}$ is committed to further strengthen the capacity and effectiveness of the Party, the state apparatus and the armed forces, such as the 2015 plan to reduce 300,000 officers and other ranks from the PLA in order to streamline its organization and strengthen its combat readiness.

As Xi asserts himself as the new leader of China he has not behaved like a strong man but acted in line with the consultative Leninist political system, which favours an institutionalized collective leadership. In dealing with highly sensitive and potentially divisive issues, such as the bringing of the disgraced former Politburo member Bo Xilai to trial and in the investigations into alleged misdeeds of the retired Politburo Standing Committee member Zhou Yongkang, Xi has moved with great deliberation. There is little doubt that $\mathrm{Xi}$ is in the driving seat but he has apparently not imposed his will on his colleagues in the Politburo and its Standing Committee in a way that would provoke an immediate backlash. What Xi has so far demonstrated is an attempt to lead from the front and yet preserve a collective leadership. He also seeks to institutionalize this by the creation of the SSC and the LSGDR. Xi will stay the course, but whether vested interests will attempt to fight back remains to be seen.

As consultative Leninism consolidates and the Party under Xi gains further in confidence and competence, it is likely to take bolder steps to deepen reform. It should imply greater scope being given to NGOs and private citizens to operate as long as they pose no challenge to the Party while dissidents' scope to articulate themselves will be restricted more tightly. Reinvigoration of specific Maoist or highly modified Confucian ideas will be 
adopted where the Party believes they can enhance its ability to govern or improve its moral authority. But they will not lead to a full scale restoration of either Maoism or Confucianism as the state ideology. The bottom line remains unchanged - the dominance of the Party, even if intra-party reforms, such as greater 'inner party democracy' may appear to make the top leader more responsive to others than his predecessors. Indeed, the increased scope for debate among party leaders is one of the means through which the Party enhances consultative Leninism and improves on its development model. Xi will also maximize the value of the mass-line and associated consultative elements to strengthen the Party's capacity to reach out to the masses. These considerations will drive political development in China that is meant to deliver a national rejuvenation in the coming decade. 